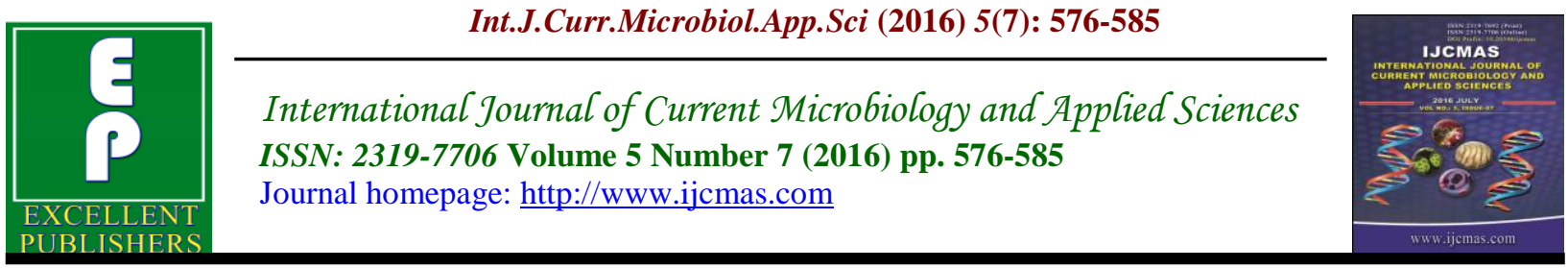

Original Research Article

http://dx.doi.org/10.20546/ijcmas.2016.507.064

\title{
Comparative Analysis of Different Biodegradable Wastes for Better Biogas Production
}

\author{
S. Dash* and P. Ray \\ Department of Microbiology, OUAT, Bhubaneswar-751003, Odisha, India \\ *Corresponding author
}

\begin{tabular}{|c|c|}
\hline & \multirow{4}{*}{$\begin{array}{l}\text { A B S T R A C T } \\
\text { Recycle and reusing waste takes little effort on our part, for a big difference to } \\
\text { the world. Wastes samples like cow dung slurry, kitchen waste slurry and de } \\
\text { oiled seed cake slurry were collected from different places aseptically and } \\
\text { microbiological analysis of the samples was undertaken. A total of } 30 \text { bacteria } \\
\text { isolates were identified on the basis of cultural, morphological and bio chemica } \\
\text { characteristics by using PIBwin software. The bacterial isolates belong to the } \\
\text { genera Bacillus, Paenibacillus, Virgibacillus, Streptococcus, Micrococcus and } \\
\text { Enterobacter sp. All the bacterial isolates were screened for different enzymatic } \\
\text { tests. Fluorescence tests were investigated which revealed that } 33.3 \% \text { bacteria } \\
\text { isolates were methanogenic. Biogas production was done by using anaerobic } \\
\text { conventional digester. Kitchen waste slurry showed maximum production of bic } \\
\text { gas than other samples. Final biogas production was done by using } \\
\text { methanogenic isolates from cow dung slurry and the isolate A4 \& A8 showed } \\
\text { maximum bio gas production. Isolate A } 4 \text { was identified as Bacillu } \\
\text { licheniformis. Further molecular identification of isolate A8 was done. It was } \\
\text { identified to be Enterobacter cloacae subsp. dissolvens strain A8 having } \\
\text { GenBank accession number KM034810. }\end{array}$} \\
\hline $\begin{array}{l}\text { K e y w o r d s } \\
\text { Anaerobic digester, } \\
\text { Biogas, Cowdung, } \\
\text { Consortia, } \\
\text { de-oiled seed cake, } \\
\text { Enterobacter } \\
\text { cloacae, Kitchen } \\
\text { waste, } \\
\text { Methanogeneic } \\
\text { bacteria. }\end{array}$ & \\
\hline Article Info & \\
\hline & \\
\hline
\end{tabular}

\section{Introduction}

Energy is one of the most important factors to global prosperity. In India alone, there are an estimated over 250 million cattle and if one third of the dung produced annually is available for production of biogas, more than 12 million biogas plants can be installed (Kashyap et al., 2003).

Biogas is a readily available energy resource that significantly reduces greenhouse-gas emission compared to the emission of landfill gas to the atmosphere
(Murphy et al., 2004). The gas is typically composed of $50-70 \%$ Methane, 30-40\% Carbon dioxide, 1-10\% Hydrogen, 1-3\% Nitrogen, $0.1 \%$ Oxygen and Carbon monoxide and trace of Hydrogen sulphide (Hasimoto et al., 1978).

Cow dung has high nitrogen content and due to pre-fermentation in the stomach of ruminant, and has been observed to be most suitable material for high yield of biogas through the study made over the years (Chonkor, 1983). Plant materials such as 
crop residues are more difficult to digest than animal wastes (manures) because of the difficulty in achieving hydrolysis of cellulosic and lignin constituents with attendant acidity in the biogas systems leading to reduction and sometimes cessation of gas flammability / gas production etc (Ofoefule et. al, 2010).

Currently, much of our biodegradable wastes such as kitchen wastes, agricultural wastes \& animal wastes are used to produce biogas. The process consists of four steps, each of which carried out by different groups of bacteria- Hydrolysis, Acidogenesis, Acetogenesis, Methanogenesis.

India has a very huge potential of tree-born non-edible oil seeds. The non-traditional seedoils available in the country, which can be exploited for this purpose, are Madhuca indica, Shorea robusta, Pongamia glabra, Mesuaferra, Mallotus philippines, Garcinia indica, Jatropha curcas and Salvadora. Out of these seeds, at the most $25 \%$ is converted into vegetable oil and the remaining $70 \%$ is rejected as toxic de-oiled seed cake and 5\% losses in the oil extraction process using mechanical expeller. However, this could be a big source of bio-energy production from the generated waste (Ram Chandra et al., 2006).

\section{Microbiology of Biogas Production}

Microbial diversity in biogas digesters is as great as that of rumen (Ramasamy et al., 1991). A total of seventeen fermentative bacterial species have been reported to play important role for production of biogas (Wolin, 1979). Furthermore, it is the nature of the substrate that determines the type and extent of the fermentative bacteria present in the digester (Zinder, 1984). It was observed that while cow dung-fed digesters supported higher amylolytic microorganisms, poultry waste-fed digesters showed higher proteolytic population (Preeti Rao et. al., 1993). Among fermentative organisms, Bacteroides succinogens, Butyrivibrio fibrisolvens, Clostridium cellobioparum, Ruminococcus albus and Clostridium sp. were predominant in cattle dung-fed digesters (Godbole et al., 1981).

Methanogens possess very limited metabolic range, using only acetate or $\mathrm{C}_{1}$ compounds $\left(\mathrm{H}_{2}\right.$ and $\mathrm{CO}_{2}$, formate, methanol, methylamines or $\mathrm{CO}$ ), with methane being the end product of the reaction. Of the methanogenic genera, Methanosarcina sp. and Methanosaeta sp. form methane by aceticlastic reaction (Preeti Rao et al., 1993). Both carbondioxide-reducing and aceticlasticmethanogens play an important role in maintaining stability of the digester. The failure in a biogas digester can occur if carbon dioxide-reducing methanogens fail to keep pace with hydrogen production (Robinson et al., 1984).

\section{Materials and Methods}

The present investigation was carried out in Department of Microbiology, O.U.A.T., Bhubaneswar. Different samples were collected from different places like Cow dung slurry and Pongamia pinnata (Karanja) de-oiled seed cake slurry from agricultural field and College of Agriculture \& Engineering Technology, Orissa University of Agriculture and Technology respectively. Kitchen waste slurry was collected from College of Engineering Bhubaneswar (CEB), Patia, Bhubaneswar. Microbial analysis of the samples was carried out to isolate aerobic and facultative anaerobic bacteria. For this 
purpose serial dilutions \& spread plate method were carried out to obtain distinct colonies. For aerobic \& facultative anaerobic bacteria, media like nutrient agar \& thioglycollate agar were used respectively. Identification of bacterial isolates was done on the basis of their colony characteristics on the basal media \& Gram staining.

Bio-chemical characterization of the isolates was done on the basis of the following bio-chemical tests including: (1) Standard test (2) Enzymatic test (3) Sugar test. For all bio-chemical tests 24 hour fresh culture was used. One control was kept in the case of each test.

\section{Fluorescence Test}

Fluorescence is presumptive evidence for methanogenic bacteria, but definitive proof requires further characterization. To observe the presence of fluorescence, the isolated colony plates were directly placed in UV Trans-illuminator and observations were noted. Positive - Development of blue-green fluorescence, Negative - no fluorescence (Dhadse et al., 2012).

\section{Biogas Production and Setup}

A bench scale study was conducted using cattle dung slurry and in combination of cow dung with kitchen waste \& de-oiled seed cake to determine the volume of biogas generation. An anaerobic conventional digester had been taken for generation of biogas. The test was carried out by digesting $250 \mathrm{ml}$ of cattle dung and $500 \mathrm{ml}$ of water (ratio 1:2) in a $1000 \mathrm{ml}$ conical flask. The flask was made air tight by using rubber cork. A plastic pipe of approx. $1 \mathrm{~m}$ long was attached to one glass tube ( 3" long) perforated into the cork of the conical flask (digester) and another glass tube into the measuring cylinder in upside down position containing acidic solution of $20 \%$ sodium sulphate. The biogas formed in the sample collected in the measuring cylinder. When an acidic solution was used as the displacement liquid, $\mathrm{CO}_{2}$ will not be absorbed and the displaced gas volume will be indicative of the total biogas generated (Dhadse et al., 2012).

For this experiment different experimental sets were taken and biogas production was determined in a per day basis. The sets or consortia were performed on the basis of their characters like methanogenic, nonmethanogenic, aerobic and facultative anaerobic. The differentiation was on the basis of fluorescence test and growth on aerobic and anaerobic media. In each digester $2 \mathrm{ml}$ of each culture was added to the cattle dung slurry to check the potential activity of the isolates on biogas generation. Sterilized cattle dung slurry was used as control

\section{Molecular Identification}

Molecular identification of the selected bacterial isolate was done by $16 \mathrm{~S}$ r DNA sequencing. For DNA Isolation Bacterial DNA isolation Kit was used (Xcelgen).

\section{Result and Discussion}

\section{Bacterial isolates from different slurries}

A total of 16, 8 and 6 bacteria were isolated from cow dung slurry, kitchen waste slurry and de-oiled seed cake slurry respectively. The bacterial isolates were designated as A1-A12 and AN1-AN4 for aerobic and facultative anaerobic bacteria from cow dung slurry, KA1-KA4 and KAN1-KAN4 for aerobic and facultative anaerobic bacteria from kitchen waste slurry and 
OA1-OA2 and OAN1-OAN4 for aerobic and facultative anaerobic bacteria from deoiled seed cake slurry respectively.

\section{Identification of Bacterial Isolates}

Identification of bacterial isolates was done by cultural, morphological \& biochemical characterization using Bergey's Manual of Systematic Bacteriology (Holt et. al, 1984) and PIBwin- software (Bryant, 2004). The bacterial isolates belong to the genera Bacillus, Paenibacillus, Virgibacillus, Streptococcus, Micrococcus and Enterobacter sp.

\section{Bacterial Isolates from Cow Dung Slurry}

Out of 16 bacterial isolates, 11 and 5 isolates were found to be Gram positive rods and Gram negative rods respectively. Obtaining biochemical tests, all the bacterial isolates $(100 \%)$ were found to be positive for citrate, nitrate, gas production and showed positive for VP, catalase, oxidase, mannitol by $56.25 \%, 68.75 \%$, $68.75 \%, 50 \%$ isolates respectively while indole and methyl red negative for all the isolates. All the bacterial isolates showed sugar utilization positive.

\section{Bacterial isolates from kitchen waste slurry}

Out of 8 bacterial isolates, 4 isolates were found to be Gram positive rods, 4 isolates found to be Gram positive coccus. The bacterial isolates $(50 \%)$ were found to be indole, methyl red, citrate, catalase, oxidase positive while $87.5 \%$ were mannitol \& gas production positive. All the isolates were VP negative and nitrate positive. The isolates $(75 \%)$ were positive to maltose, sucrose, raffinose, arabinose, cellobiose while $50 \%$ to xylose; $62.5 \%$ showed dextrose, lactose, inositol, rhamnose, trehalose positive; $37.5 \%$ showed fructose positive; $87.5 \%$ showed glucose positive and $100 \%$ showed sorbitol and mellibiose positive.

\section{Bacterial isolates from oil cake slurry}

Out of 6 bacterial isolates, 2 and 4 bacterial isolates were found to be Gram positive rods, \& Gram negative rods respectively. All the bacterial isolates $(100 \%)$ were found to be VP, citrate, catalase, gas production, mannitol and nitrate positive while $66.6 \%, 33.3 \%, 83.3 \%$ isolates were found to be indole, methyl red, oxidase negative respectively. The isolates $(83.3 \%)$ showed maltose, raffinose, rhamnose, inositol positive, $66.6 \%$ showed xylose, dextrose, sucrose, sorbitol, cellobiose positive while $16.6 \%$ showed lactose and fructose positive. All the bacterial isolates $(100 \%)$ showed glucose, arabinose, trehalose positive and $50 \%$ showed mellibiose positive.

\section{Enzymatic Characterization of Bacterial Isolates}

All the bacterial isolates were screened for enzymatic activities by taking pseudo selective agar at $37^{\circ} \mathrm{C}$ for 72 hours. The investigated enzymes were amylase, chitinase, caesinase, cellulase and gelatinase. (Table 1)

\section{Fluoroscence Test of Bacterial Isolates}

All the bacterial isolates were investigated for methanogenic character by the fluorescence test. It was revealed that out of 30 bacterial isolates, 10 bacterial isolates (33.3\%) were methanogenic. All the isolates obtained from de-oiled seed cake slurry were found to be non methanogenic. (Table 2) (Fig.1) 


\section{Biogas Production of Bacterial Isolates}

All the bacterial isolates were investigated for biogas production by using an anaerobic conventional digester.

Table 3 depicts the biogas production form cow dung slurry bacterial isolates. It was observed that anaerobic methanogenic consortia showed a total of higher production of gas $\left(402.876 \mathrm{~cm}^{3}\right)$ followed by cow dung slurry (no addition of bacterial isolates) of $298.623 \mathrm{~cm}^{3}$. Further methanogenic isolates were used for biogas production (Table 4). The combination of the methanogenic bacterial isolate A4 and
A8 showed maximum biogas production. Another experiment was done taking combinations of kitchen waste slurry as mentioned in Table 5. From this experiment it was observed that maximum bio gas production was found in set 7 (cow dung + facultative anaerobic non methanogenic isolates from kitchen waste slurry + kitchen waste) which was $568.974 \mathrm{~cm}^{3}$ in three days followed by set 6 (cow dung + facultative anaerobic non methanogenic isolates from kitchen waste slurry) of $415.245 \mathrm{~cm}^{3}$ and minimum was found in case of set 4 (cow dung + aerobic non methanogenic isolates from kitchen waste slurry) of $61.845 \mathrm{~cm}^{3}$ in three days.

Table.1 Enzymatic characterization of the bacterial isolates

\begin{tabular}{|c|c|c|c|c|c|}
\hline \multirow{2}{*}{$\begin{array}{l}\text { Bacterial } \\
\text { Isolates }\end{array}$} & \multicolumn{5}{|c|}{ Enzymatic Tests } \\
\hline & Amylase & Chitinase & Caesinase & Cellulase & Gelatinase \\
\hline A1 & - & + & - & + & - \\
\hline A2 & - & + & - & + & - \\
\hline A3 & - & + & - & + & - \\
\hline A4 & - & + & - & + & - \\
\hline A5 & - & + & - & + & - \\
\hline A6 & - & + & - & + & - \\
\hline A7 & - & + & - & + & - \\
\hline A8 & - & + & - & + & - \\
\hline A9 & - & + & - & + & - \\
\hline A10 & - & + & - & + & - \\
\hline A11 & - & + & - & + & - \\
\hline A12 & - & + & - & + & - \\
\hline AN1 & - & + & - & + & - \\
\hline AN2 & - & + & - & + & - \\
\hline AN3 & - & + & - & + & - \\
\hline AN4 & - & + & - & + & - \\
\hline KA1 & - & + & + & - & + \\
\hline KA2 & - & - & + & - & - \\
\hline KA3 & - & + & + & - & + \\
\hline KA4 & - & + & - & - & - \\
\hline KAN1 & - & + & + & - & + \\
\hline KAN2 & - & - & + & - & + \\
\hline KAN3 & - & - & - & - & + \\
\hline KAN4 & - & - & + & - & + \\
\hline OA1 & - & + & + & - & $=$ \\
\hline OA2 & + & + & + & - & - \\
\hline OAN1 & - & + & + & - & - \\
\hline OAN2 & + & - & + & - & - \\
\hline OAN3 & - & + & + & - & - \\
\hline OAN4 & + & + & + & - & + \\
\hline
\end{tabular}


Table.2 Fluorescence test for the bacterial isolates

\begin{tabular}{|c|c|c|c|}
\hline Bacterial Isolates & Methanogenecity & Bacterial Isolates & Methanogenecity \\
\hline A1 & - & AN4 & - \\
\hline A2 & + & KA1 & - \\
\hline A3 & + & KA2 & + \\
\hline A4 & + & KA3 & - \\
\hline A5 & - & KA4 & + \\
\hline A6 & - & KAN1 & - \\
\hline A7 & - & KAN2 & - \\
\hline A8 & + & KAN3 & - \\
\hline A9 & + & KAN4 & - \\
\hline A10 & - & OA1 & - \\
\hline A11 & + & OA2 & - \\
\hline A12 & - & OAN1 & - \\
\hline AN1 & + & OAN2 & - \\
\hline AN2 & + & OAN3 & - \\
\hline AN3 & - & OAN4 & - \\
\hline
\end{tabular}

Table.3 Combinations of bacterial isolates for biogas production from cowdung slurry

\begin{tabular}{|c|c|c|c|c|c|c|}
\hline \multirow{2}{*}{ Days } & \multicolumn{7}{|c|}{ Biogas production $\left(\mathrm{cm}^{3}\right)$} \\
\cline { 2 - 7 } & Set 1 & Set 2 & Set 3 & Set 4 & Set 5 & Set 6 \\
\hline 1 & 72.447 & 0 & 26.505 & 61.845 & 100.719 & 0 \\
\hline 2 & 98.952 & 56.544 & 35.340 & 93.651 & 141.36 & 0 \\
\hline 3 & 127.224 & 29.971 & 47.709 & 130.758 & 160.797 & 0 \\
\hline Total & 298.623 & 79.515 & 109.554 & 286.254 & 402.876 & 0 \\
\hline
\end{tabular}

Set 1: Slurry (only cow dung); Set 2: cow dung + aerobic non methanogenic isolates from cow dung slurry; Set 3: cow dung + aerobic methanogenic isolates from cow dung slurry; Set 4: cow dung + facultative anaerobic non methanogenic isolates from cow dung slurry; Set 5: cow dung + facultative anaerobic methanogenic isolates from cow dung slurry, Set 6: control (sterilized cow dung).

Table.4 Different sets for biogas production from methanogenic isolates from cow dung slurry

\begin{tabular}{|c|c|c|c|c|}
\hline \multirow{2}{*}{ DAYS } & \multicolumn{4}{|c|}{ Biogas production $\left(\mathrm{cm}^{3}\right)$} \\
\cline { 2 - 5 } & A 2 \& A 3 & A 4 \& A 8 & A9 \& A 11 & AN1 \& AN2 \\
\hline 1 & 22.971 & 73.330 & 40.641 & 56.544 \\
\hline 2 & 23.854 & 84.816 & 33.573 & 83.932 \\
\hline 3 & 25.621 & 100.719 & 44.175 & 116.622 \\
\hline Total & 72.446 & 258.865 & 118.389 & 257.098 \\
\hline
\end{tabular}


Table.5 Different sets of bacterial isolates for biogas production from kitchen waste slurry

\begin{tabular}{|c|c|l|l|l|l|l|l|c|}
\hline \multirow{2}{*}{ DAYS } & \multicolumn{7}{|c|}{ Biogas production $\left(\mathrm{cm}^{3}\right)$} \\
\cline { 2 - 9 } & Set 1 & Set 2 & Set 3 & Set 4 & Set 5 & Set 6 & Set 7 & Set 8 \\
\hline 1 & 53.010 & 26.505 & 77.748 & 0 & 30.039 & 79.515 & 91.884 & 0 \\
\hline 2 & 63.612 & 68.913 & 91.884 & 30.039 & 37.107 & 121.923 & 171.399 & 0 \\
\hline 3 & 74.214 & 80.399 & 111.321 & 37.107 & 61.845 & 213.807 & 305.691 & 0 \\
\hline Total & 190.836 & 175.816 & 280.953 & 61.845 & 128.985 & 415.245 & 568.974 & 0 \\
\hline
\end{tabular}

Set 1: Slurry i.e. cow dung + kitchen waste; Set 2 : cow dung + aerobic methanogenic isolates from kitchen waste slurry; Set 3: cow dung + aerobic methanogenic isolates from kitchen waste slurry + kitchen waste; Set 4: cow dung +aerobic nonmethanogenic isolates from kitchen waste slurry; Set 5: cow dung +aerobic nonmethanogenic isolates from kitchen waste slurry + kitchen waste; Set 6: cow dung + facultative anaerobic non methanogenic isolates from kitchen waste slurry; Set 7: cow dung + facultative anaerobic non methanogenic isolates from kitchen waste slurry + kitchen waste; Set 8: control (sterilized cow dung).

Table.6 Different sets of bacterial isolates for biogas production from de-oiled seed cake slurry

\begin{tabular}{|c|c|c|c|c|c|c|}
\hline \multirow{2}{*}{ DAYS } & \multicolumn{6}{|c|}{ Biogas production $\left(\mathrm{cm}^{3}\right)$} \\
\cline { 2 - 7 } & Set 1 & Set 2 & Set 3 & Set 4 & Set 5 & Set 6 \\
\hline 1 & 0 & 14.136 & 100.719 & 65.379 & 125.457 & 0 \\
\hline 2 & 22.971 & 45.942 & 125.457 & 118.389 & 157.263 & 0 \\
\hline 3 & 61.845 & 88.350 & 144.894 & 144.894 & 219.108 & 0 \\
\hline Total & 84.816 & 148.428 & 371.070 & 328.662 & 501.828 & 0 \\
\hline
\end{tabular}

Fig.1 Fluorescence test for the bacterial isolates.

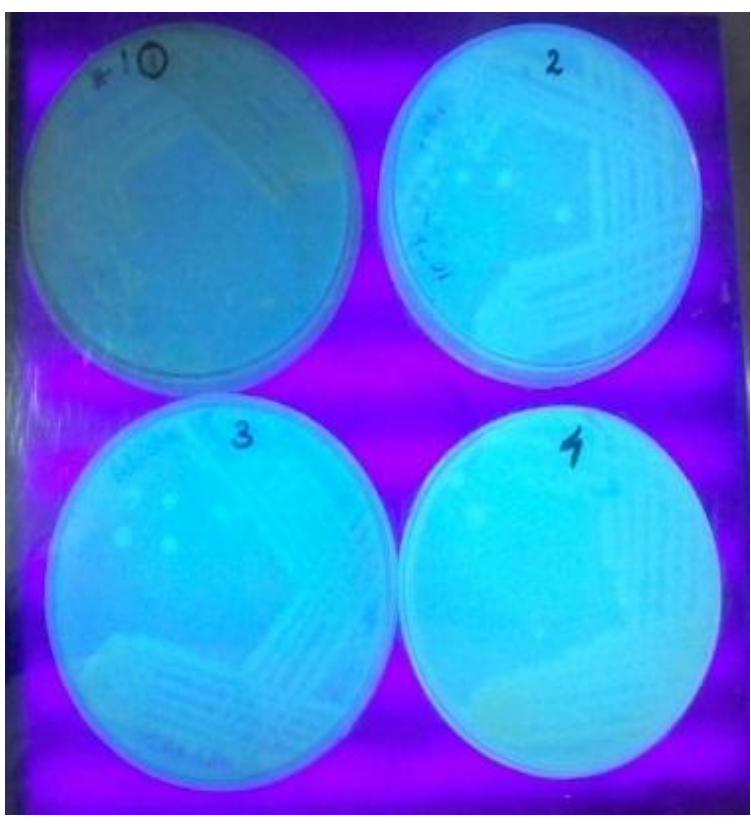

(A)

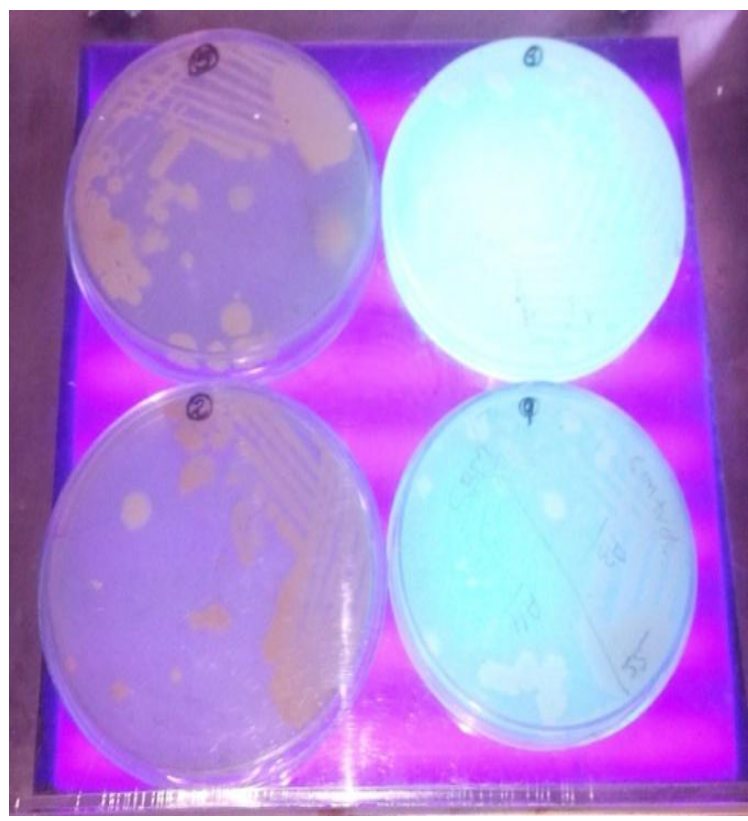

(B)

(A) - Plate 1 showed no fluorescence while plate $2,3 \& 4$ showed fluorescence.

(B) - Plate $1 \& 2$ showed no fluorescence while plate $3 \& 4$ showed fluorescence. 
Fig.2 Phylogenetic tree of Enterobacter cloacae subsp. dissolvens strain A8.

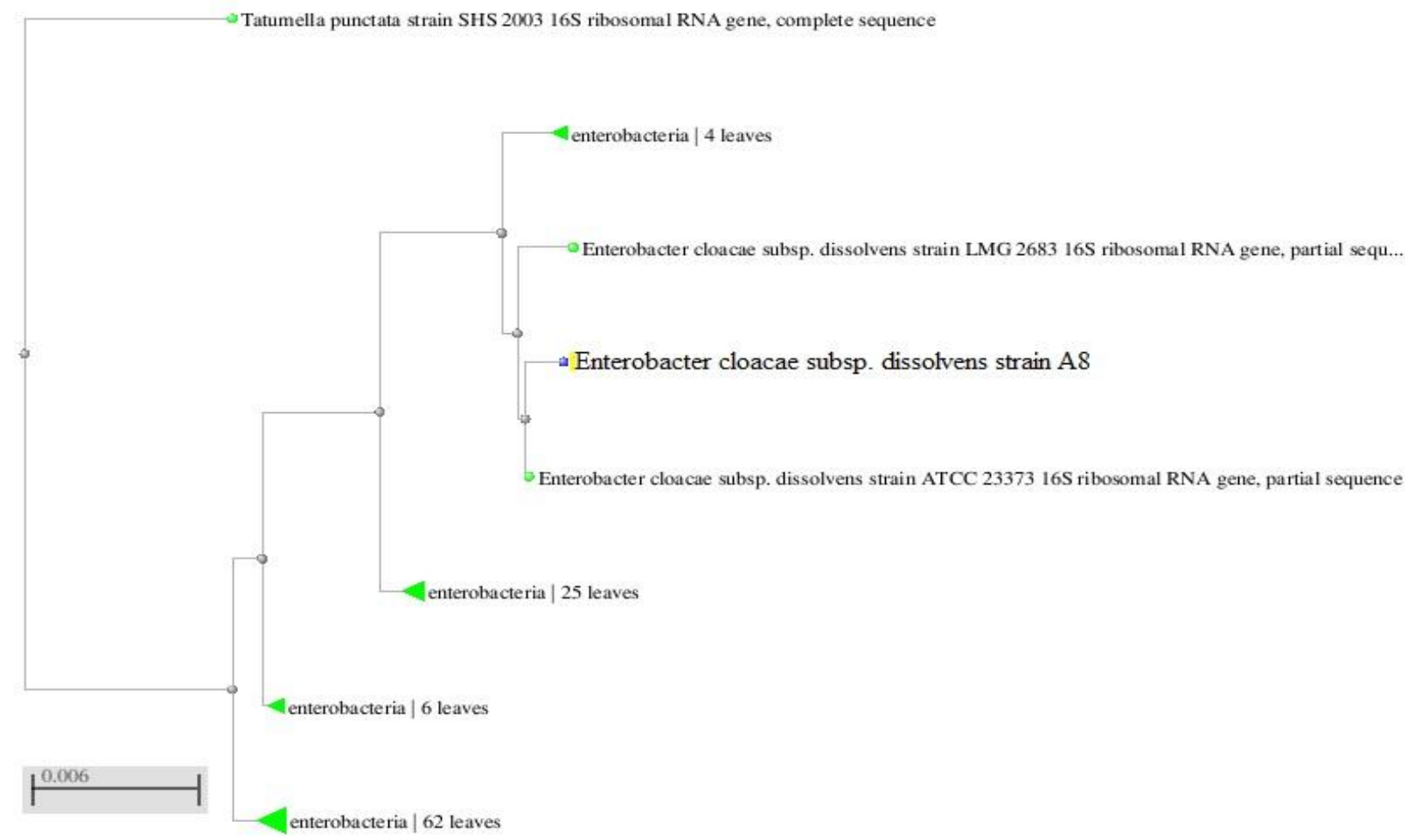

From the experiment performed using combinations of bacterial isolates from deoiled seed cake slurry observed that maximum bio gas production was found in set 5 (cow dung + facultative anaerobic non methanogenic isolates from seed cake slurry + seed cake) of $501.828 \mathrm{~cm}^{3}$ in three days followed by set 3 (cow dung + aerobic non methanogenic bacterial isolates from oil cake slurry + seed cake) of $371.070 \mathrm{~cm}^{3}$ and minimum was found in case of set 1 (cow dung + seed cake) of $84.816 \mathrm{~cm}^{3}$ in three days (Table 6).

\section{Molecular Identification of the Potent Bacterial Isolate}

The 16S r DNA based molecular technique revealed that the isolate A8 was Enterobacter cloacae subsp. dissolvens strain A8 having GenBank accession number KM034810. Phylogenetic tree reveales that Enterobacter cloacae subsp. dissolvens strain ATCC 23373 is nearer to the bacterial isolate A8 (Fig 2).

It was reported that methanogenic bacteria isolated from cow dung slurry contributed more biogas production than non methanogenic bacteria (Dhadse et al., 2012). The $16 \mathrm{~S}$ r DNA based molecular technique revealed that the isolate A8 was Enterobacter cloacae subsp. dissolvens strain A8. There is another report of using Enterobacter cloacae for improved bio gas production by Kovacs et al. (2013). Facultative anaerobic isolates have the potential to metabolize methane and takes part in methane production. Kitchen waste with cow dung produced more gas. This result corroborates with the report of Ranade et al. (1987) who used market waste and reported a 200 litres capacity biogas plant produced $30 \cdot 2$ litres $\mathrm{kg}$ per day at 20 days HRT (hydraulic retention time). Biogas production is established using de- 
oiled seed cake plus cow dung which corroborates with the result of Kumar et. al. (2013) that the maximum biogas production was observed for the treatment S1 (Cow dung $0.680 \mathrm{~kg}$, Volume of water 0.820 lit) followed by S5 (pongamia deoiled seed cake $0.160 \mathrm{~kg}$, Volume of water 1.340 lit).

In conclusion, biogas is a promising renewable energy carrier as the technology of its production combines the elimination of biodegradable waste such as animal wastes, kitchen wastes and agricultural waste. Anaerobic digestion is a treatment that composts these wastes in the absence of oxygen producing biogas which can generate heat and energy. Although the combination of the bacterial isolate A4 and A8 showed maximum biogas production, the combined effect of cow dung and kitchen waste proved to be a better substrate for biogas production.

\section{Acknowledgement}

The authors are grateful to Dr. B. B. Mishra (HOD) Department of Microbiology, OUAT, Bhubaneswar, for providing support during the research.

\section{References}

Bryant, T.N. 2004. PIBWin- software for probabilistic identification, J. Appl. Microbiol., 97(6): 1326-7.

Chandra, R., Vijay, V.K. and Subbarao, P.M.V. 2006. A Study on Biogas Generation from Non-edible Oil Seed Cakes: Potential and Prospects India. The $2^{\text {nd }}$ Joint International Conference on "Sustainable Energy and Environ., E-007 (P).

Chonkar, P.K. 1983. Microbial ecology during anaerobic fermentation of cellulose waste materials in S. K. Vyas, N.S., Biogas technology
USG publisher, Luthiana India., pp, 21-26.

Dhadse, S., Kankal, N.C. and Kumari, B. 2012. Study of diverse methanogenic and non-methanogenic bacteria used for the enhancement of biogas production. Int. J. Life Sci. Biotechnol. Pharma Res., 1.

Godbole, S.H., Gore, J.A., Ranade, D.R. 1981. Biovignyanam, 7: 107-113.

Hasimoto, G., Varriel, H. 1978. Factors affecting methane yield and production rate. Americansocietyof agricultural Engineers (ASAE). St Joseph, ML: 4908 http://www.usaid.gov/stores/Srilankabiogas, Htm, pp 68.

Holt, J.C., Krieg, N.R. (eds., 1984). Bergey's Manual of Systematic Bacteriology, 1st ed., vol.1, Williams and Wilkins, Baltimore.

Kashyap, D.R., Dadhich, K.S. and Sharma, S. K. 2003. Biomethanation under psychrophilic conditions: a review. Bioresour. Technol., 87: 147- 153.

Kumar, D., Swarnkar, N.K., Vijayakumary, P. 2013. Biogas Production Potential of Pungam Oil Cake. International J. Chem. Tech. Res., 5(2): 741-746.

Kovacs, K.L, Acs, N., Kovacs, E., Bagi, Z., Wirth, R., Rakhely, G., Strang, O. 2013. Improvement of Biogas Production by Bioaugmentation. BioMed. Res. Int.

Murphy, J.D., McKeogh D., Kiely, G. 2004. Technical/ economic / environmental analysis of biogas utilization. Appl. Energy, 77: 407-427.

Ofoefule, Akuzuo, U., Onukwuli, Okechukwu, D. 2010. Biogas production from blends of bambara nut (Vigna subterranea) chaff with some animal and plant wastes. Adv. Appl. Sci. Res., 1(3): 98-105. 
Preeti Rao, P. Shivaraj, D and Seenayya, G. 1993. Indian J. Microbial., 33: 185189.

Ramasamy, K., Nagamani, B. and Kalaichelvan, G. 1991. in 31st Annual Conference of AMI held at TNAU, Coimbatore, pp. 96

Ranade, D.R., Yeole, T.Y. and Godbole,
S.H. 1987. Production of biogas from market waste. Biomass, 13(3): 147153.

Robinson, J.A. and Tiedje, J.M. 1984. Arch. Microbiol., 137: 26-32.

Wolin, M.J. 1974. Adv. Microbial Ecol., 3: 49-77.

Zinder, S.H. 1984. ASM News, 50: 294-298.

\section{How to cite this article:}

Dash, S., and Ray, P. 2016. Comparative Analysis of Different Biodegradable Wastes for Better Biogas Production. Int.J.Curr.Microbiol.App.Sci. 5(7): 576-585.

doi: http://dx.doi.org/10.20546/ijcmas.2016.507.064 